\title{
Sex uten grenser?
}

Det har hersket en utbredt skepsis blant forskere til å spørre ungdom om seksuelle krenkelser og overgrep. Innvendingene har variert fra at svarprosenten i studiene vil gå dramatisk ned til at spørsmålene kan føre til alvorlige psykiske reaksjoner og bryte med god forskningsetikk. Omfanget av vold og overgrep mot barn og ungdom har derfor i liten grad vært systematisk undersøkt. Denne mangelen på overvåking strider mot barnekonvensjonen og er et internasjonalt problem. FN satte fokus på problematikken i 2006 (1), og i Norge førte det til at flere rapporter ble publisert $(2,3)$. I dette nummer av Tidsskriftet presenteres ytterligere en studie som dokumenterer det rapportene også viste: Selv om seksuelle overgrep er vanskelig å snakke om, har ungdommene vist stor vilje til å besvare spørsmålene i spørreskjemabaserte studier (4). Denne tilliten er inspirerende og gir muligheter til å høste ny kunnskap om hva som kan hjelpe ungdom som sliter med konsekvenser av overgrep.

Mange ungdommer rapporterer at «de var for unge til å forstå» hva de ble involvert $i$, eller de ble utsatt for overtalelse, press eller fysisk vold når overgrepet skjedde (2). Det er oftere jenter som utsettes for overgrep enn gutter. Eksempelvis rapporterte i gjennomsnitt $6 \%$ av jentene og $1,6 \%$ av guttene i 10 . klasse at de var utsatt for et seksuelt overgrep siste år (3). Selv om metoder og utvalg er forskjellige i studiene, er omfangstallene sammenliknbare og kjønnsforskjellen markant (4). Både barn og ungdommer har ofte hatt stor tillit til den som har begått overgrepet. Jenter oppgir nesten utelukkende at de er blitt utsatt for overgrep av en gutt eller mann, mens guttene rapporterer at jenter eller kvinner har utført overgrep i seks av ti tilfeller (2). Mens seksuelle overgrep mot mindre barn oftest blir begått av overgripere som er betydelig eldre enn barnet, er det ofte en person som selv er i tenårene som begår mange av de seksuelle krenkelsene og overgrep ungdom utsettes for $(2,4)$. Denne kunnskapen reiser mange spørsmål om hva som går galt i mange unge menneskers seksuelle relasjoner: Forstår og respekterer de hverandres grenser? Hva forstår ungdom som et gjensidig samtykke til sex? Opplever mange jenter det som tatt for gitt at gutter kan «ta seg til rette» innenfor rammen av kjæresterelasjoner? Blir jenters atferd styrt av slike forventinger?

«Han truet med at hvis jeg ikke hadde sex med han så kom han til å slå opp med meg. Jeg ville ikke, men lot ham (overtale meg) og det angrer jeg på den dag i dag.»»

Utsagnet er en ung jentes beretning om uønsket sex i en kjæresterelasjon (2) og illustrerer hvordan ungdom kan la seg presse til å delta $\mathrm{i}$ handlinger de senere angrer på og tar avstand fra fordi de er usikre på hvordan de setter sine grenser. I Dahle og medarbeideres studie har $21,6 \%$ av jentene negative erfaringer knyttet til sin seksuelle debut (4). Tallene tyder på at vi nå er nødt til å fokusere mer på unge menneskers grensesetting når det gjelder sex, og på gjensidighet og respekt for hverandres ønsker om sex.

At mange ungdommer også rapporterer at jevnaldrende begår seksuelle overgrep med trusler om vold (10\%) og at mange jenter forteller at de ble holdt fast under overgrepet (38\%) (2), får for alvor varsellamper til å lyse: Hva får unge mennesker til å utøve vold mot hverandre på denne måten? Hva fører til at respekten for den andres grenser totalt opphører?
Selv om seksuelle overgrep sjelden er tema for konsultasjoner på legekontoret (5), viser gjentatte studier at overgrep er assosiert med psykiske og somatiske helseplager. Eksempelvis hadde tiendeklassinger som siste år hadde vært utsatt for seksuelle overgrep eller vold i Norge, mer psykiske symptomer og smerteplager enn andre ungdommer (3). Også Dahle og medarbeidere fant i sin studie at seksuelle hendelser der ungdom følte seg presset til sex eller hadde opplevd overgrep, var knyttet til angst, depressive plager og somatiske symptomer (4). Vennestøtte, forståelse og støtte hjemme og selvtillit blir i denne studien fremhevet som viktige faktorer for å redusere lidelse. Dessverre er det slik at seksuelle overgrep som oftest ikke blir fortalt videre, verken av den som utfører overgrepene eller av den som rammes (5). Mangel på åpenhet om problematikken fører til at hjelp og støtte er utenfor rekkevidde. Sviktende kunnskap hos leger, helsesøstre og lærere bidrar ytterligere til at hjelpetilbudene ikke gjøres tilgjengelige.

Studier viser klar assosiasjon mellom alkoholrus og forekomst av seksuelle overgrep. Dahle og medarbeidere viser at ungdom med negative seksuelle erfaringer oftere var ruset under sin seksuelle debut enn ungdom uten negative erfaringer (4). Mye tyder på at overgrep lettere utøves i sosiale situasjoner der utøver og offer er beruset og at alkohol bidrar til at man tør mer. En annen forklaring er at ungdom som har vært utsatt for seksuelle overgrep, kan ty til rus for å takle smerte, angst og depressive symptomer i etterkant. Dahle og medarbeidere konkluderer med at overgrep kan forebygges gjennom senere og edruelig seksuell debut (4). Ungdoms modenhet varierer imidlertid i stor grad, både mentalt og fysisk, og hva blir da «riktig» alder for seksuell debut? Det er også lite som tyder på at ungdom drikker mindre dess eldre de blir. Til tross for at det har fremkommet ny kunnskap om seksuelle krenkelser og overgrep, hersker det en øredøvende stillhet om forebyggende tiltak landet over. Neste runde bør innebære handling, også i de spesialiserte helsetjenestene, som ennå ikke har implementert kunnskapsbaserte behandlingstilbud for depressive og posttraumatiske stresssymptomer etter overgrep (6).

\section{Grete Dyb}

grete.dyb@nkvts.unirand.no

Grete Dyb (f. 1959) er førsteamanuensis ved Institutt for klinisk medisin ved Universitetet i Oslo og forsker ved Nasjonalt kunnskapssenter om vold og traumatisk stress. Hun er spesialist i barne- og ungdomspsykiatri.

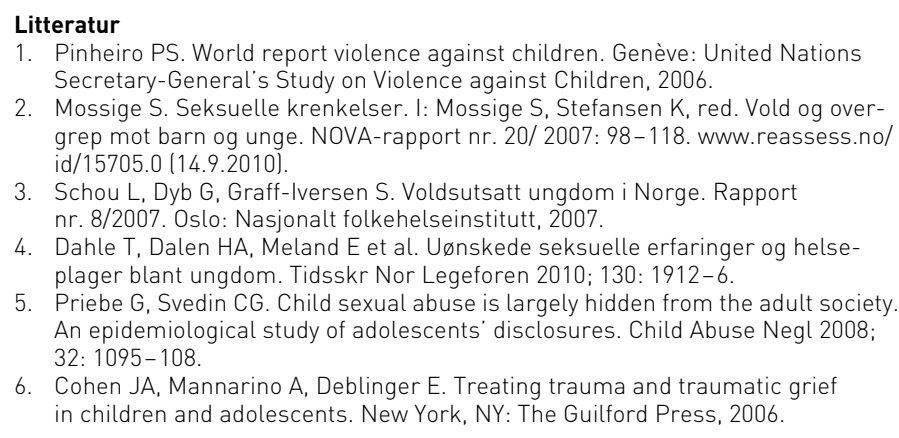

6. Cohen JA, Mannarino A, Deblinger E. Treating trauma and traumatic grief in children and adolescents. New York, NY: The Guilford Press, 2006. 